Sari Pediatri, Vol. 7, No. 3, Desember 2005: 132 - 135

\title{
Manifestasi Gastrointestinal Akibat Alergi Makanan
}

\author{
Sukmawati, Hendra Santoso, I Kompyang Gede Suandi
}

\begin{abstract}
Alergi makanan adalah bagian dari reaksi simpang makanan yang didasari proses imunologis. Berbagai mekanisme pertahanan saluran cerna baik imunologik dan non imunologik memegang peran penting dalam mencegah terjadinya alergi makanan. Berdasarkan proses imun yang mendasari, terjadinya alergi makanan dibedakan menjadi tiga jalur yakni reaksi yang diperantarai IgE ( $I g E$ mediated), yang tidak diperantarai $\operatorname{IgE}$ (non-IgE mediated), dan mekanisme campuran yang melibatkan IgE dan non IgE. Gejala gastro intestinal akibat alergi makanan sangat bervariasi dari perasaaan nyeri, mual, muntah, diare, malabsorpsi dan kehilangan protein hingga terjadi gangguan pertumbuhan. Umumnya alergi makanan akan menghilang pada umur 5-6 tahun kecuali, kacang tanah dan alergi terhadap sejenis ikan laut dan kerang-kerangan.
\end{abstract}

Kata kunci: alergi makanan, gejala gastrointestinal

$\mathcal{A}$ Tergi makanan adalah suatu kumpulan gejala yang mengenai banyak organ dan sistem tubuh yang disebabkan oleh alergi terhadap bahan makanan. ${ }^{1}$ Alergi makanan harus dibedakan dengan reaksi simpang makanan dan intoleransi makanan. Reaksi simpang makanan adalah suatu istilah umum untuk reaksi yang tidak diinginkan terhadap makanan. Reaksi ini dapat merupakan reaksi sekunder terhadap alergi makanan atau intoleransi makanan. Intoleransi makanan adalah reaksi yang tidak diinginkan terhadap makanan yang bersifat non imunologik. ${ }^{2,3}$

Angka kejadian alergi makanan bervariasi pada tiap negara, diperkirakan $2 \%$ dari seluruh populasi dan terus meningkat dalam dekade terakhir., 4 Alergi makanan paling sering diderita pada tahun-tahun pertama kehidupan yakni 6\% anak berumur kurang dari 3 tahun. $^{6}$

\footnotetext{
Alamat korespondensi:

Prof. dr. Hendra Santoso, SpA(K), Subbagian Alergi Imunologi, dr. I Kompyang Gede Suandi, SpA Subbagian Gizi, dr. Sukmawati PPDS IKA FK UNUD-RS Sanglah Jl. Pulau Nias No. 1 Denpasar.

Telp 0361-244 038. Fax. 0361257387
}

Faktor genetik memiliki peran penting terhadap kejadian alergi makanan. Kemungkinan anak menjadi alergi adalah 58\% bila kedua orang tua atopik, 38\% bila salah satu orang tua atopik dan hanya $12,5 \%$ bila kedua orang tuanya tidak atopik. ${ }^{7}$

\section{Alergen makanan}

Variasi makanan manusia di dunia sangat besar, namun hanya sedikit makanan yang menyebabkan alergi. ${ }^{1}$ Asupan makanan dan cara pengolahan mempunyai peranan penting dalam terjadinya alergi makanan. Sebagai contoh, konsumsi kacang tanah di Amerika Serikat dan Cina hampir sama namun sangat jarang ditemukan alergi kacang tanah di Cina. Orang Cina lebih banyak makan kacang tanah yang direbus atau digoreng sedangkan orang Amerika lebih banyak makan kacang tanah yang digoreng kering (dry-roasted). Panas yang lebih tinggi pada proses penggorengan kering $\left(180^{\circ}\right)$ meningkatkan sifat alergenik dari protein kacang tanah. ${ }^{8}$

Epitop (tempat melekatnya IgE) pada protein juga menentukan sifat alergenitas dari protein. Epitop 
sequential (terdiri dari asam amino berurutan dari protein yang sama) tahan terhadap pemanasan, asam dan enzim degradasi sehingga sulit kehilangan sifat alergenitasnya. Hal sebaliknya terjadi pada epitop non sequential (discontinuous) yaitu epitop yang mengandung asam amino dari protein berbeda. ${ }^{4,8} \mathrm{Hal}$ ini ditunjukkan pada anak-anak dengan alergi susu sapi yang menetap ternyata memiliki IgE yang lebih tinggi pada epitop sequential dari protein ás1, ás2 dan êcasein. ${ }^{4}$

Sensitisasi alergen makanan dapat terjadi melalui dua cara yakni melalui traktus intestinal (tipe 1) dan inhalasi (tipe 2). Sebagian besar alergen makanan tipe 1 adalah glikoprotein yang larut dalam air yang memiliki ukuran $10-70 \mathrm{kDa}$, stabil dalam panas, asam dan enzim protease. ${ }^{8,9}$ Profilin, yang merupakan proporsi terbesar dari alergen tipe 2 seringkali menunjukkan reaksi silang dengan tepung sari (pollen). Pasien seringkali tersensitisasi oleh tepung sari karena reaksi silang dengan profilin yang terdapat dalam buah dan sayuran. ${ }^{8}$

Berbagai jenis makanan yang menimbulkan alergi pada anak dapat digolongkan menurut kekerapannya dalam menimbulkan reaksi sebagai berikut. ${ }^{1}$

- Golongan makanan yang paling sering menimbulkan alergi adalah susu sapi/kambing, telur, kacang tanah, nuts, ikan laut, kedelai dan gandum.

- Golongan makanan yang relatif jarang menimbulkan alergi adalah daging ayam, daging babi, daging sapi, kentang, coklat, jagung, nasi, jeruk dan bahan aditif makanan.

Hendra Santoso ${ }^{10}$ di Denpasar melaporkan penyebab alergi makanan pada anak tersering adalah coklat, kacang tanah, semangka, mentimun dan rambutan.

\section{Patogenesis alergi makanan}

Sejak lahir berbagai antigen makanan asing secara rutin masuk ke dalam saluran cerna, namun sangat jarang menimbulkan gejala klinis. Hal ini karena adanya berbagai mekanisme pertahanan saluran cerna baik yang bersifat imunologik maupun non imunologik. ${ }^{1,11,12}$

Berbagai mekanisme pertahanan saluran cerna adalah mekanisme imunologik dan non imunologik.
1. Mekanisme non imunologik/fisiologik

- Barier terpenting dalam mencegah antigen asing memasuki mukosa saluran cerna adalah pemecahan antigen asing oleh berbagai enzim proteolitik yang terdapat di mulut, lambung, usus kecil dan kolon. Peptida yang terdiri dari < 8-10 asam amino kurang bersifat imunogenenik. $^{12}$

- Lapisan mukus sepanjang mukosa oropharing hingga rektum membentuk lapisan tebal menutupi kripte. Lapisan ini mencegah penetrasi antigen ke dalam epitel usus. ${ }^{1,12}$

- Intestinal epithelial cels (IECs) yang saling berkait erat pada bagian apikal dan basal sehingga membentuk suatu barier yang sulit ditembus oleh molekul besar dan hanya dapat dilewati oleh ion. Pada periode neonatal dan dalam keadaan inflamasi hubungan ini kurang kuat sehingga makromolekul dapat masuk ke dalam lamina propria. ${ }^{12}$

- Flora komensal di saluran cerna juga berperan dalam proses imun saluran cerna. Flora komensal ini berkompetisi dengan kuman patogen sehingga dapat menghambat pertumbuhan kuman patogen. ${ }^{8,12}$

\section{Mekanisme imunologik}

- Sel epithel intestinal mengekspresikan sejumlah reseptor pada permukaannya, menangkap antigen (Ag), bertindak sebagai $A g$-presenting cells (APC), dan mengaktifkan sel CD 8+dan CD $4+.^{12}$

- Sel T regulator yakni Th3 dan TR1. Antigen yang masuk menyebabkan Th3 mengaktifkan patch peyer dan mengeluarkan transforming growth factor-â (TGF-â), suatu sitokin imunosupresif yang kuat. Hal ini penting dalam terjadinya proses toleransi saluran cerna; sedangkan TR1 mensekresi IL-10 yang juga bersifat imunosupresif. ${ }^{11}$

- Imunoglobulin A sekretari berperan untuk mencegah antigen berikatan dengan sel epitel dan mengeluarkannya dari tubuh. ${ }^{11}$

Berdasarkan mekanisme imun, terjadinya alergi makanan dibagi menjadi reaksi yang diperantarai $\operatorname{IgE}$ ( IgE mediated), yang tidak diperantarai $\operatorname{IgE}$ 
(non-IgE mediated) dan mekanisme campuran yang melibatkan IgE dan non IgE, seperti tertera pada Tabel $1 .^{8,13}$

\section{Manifestasi klinis alergi makanan pada saluran gastrointestinal}

\section{Alergi makanan yang diperantarai $\operatorname{Ig} \mathrm{E}(\operatorname{Ig} E$ mediated)}

- Oral allergy syndrome (Pollen-food syndrome). Pada anak dengan oral allergy syndrome (OAS) setelah makan sayur dan atau buah segar tertentu akan segera timbul rasa gatal di mulut, angioedem pada bibir, lidah dan palatum. ${ }^{8}$ Umumnya anak dengan OAS mempunyai reaksi silang, sebagai contoh alergi terhadap melon bereaksi silang dengan alergi terhadap ragweed, atau alergi terhadap apel, peach dan chery bereaksi silang dengan alergi terhadap pollen birch dengan gejala seperti rhinitis alergi. ${ }^{13}$

- Reaksi anafilaksis gastrointestinal. Reaksi anafilaksis gastrointestinal bersifat akut, biasanya dalam beberapa menit hingga 1-2 jam, berupa mual, muntah dan nyeri perut. Diare dapat terjadi beberapa jam setelah timbulnya gejala awal. ${ }^{8}$ Penyebab yang tersering adalah alergi terhadap susu sapi, telur, kacang tanah, kedelai, gandum, dan ikan laut. ${ }^{13}$ Reaksi ini terjadi akibat dilepaskannya berbagai mediator oleh sel mast seperti histamin. Meski tergolong reaksi alergi tipe cepat, gejala gastrointestinal tidak selalu disertai dengan reaksi sistemik. ${ }^{13}$

2. Alergi makanan yang tidak diperantarai $\operatorname{IgE}$ (non IgE mediated)

- Proktitis / protokolitis. Gangguan ini biasanya timbul pada bulan-bulan pertama kehidupan, dengan rerata umur 2 bulan. Protein susu sapi dan protein kedelai (lebih jarang) adalah pencetus tersering. Bayi-bayi ini secara umum tampak sehat namun pada feses dapat ditemukan bintik-bintik darah dengan lendir. Pada pemeriksaan endoskopi ditemukan kolitis fokal atau difus dengan udem dan erosi. Pada biopsi didapatkan infiltrasi eosinofil dan kadang hiperplasia nodular. ${ }^{13}$

- Sindrom enteropati. Gangguan ini ditandai dengan muntah ( $2 / 3$ kasus) dan diare yang berkepanjangan. Hal ini menyebabkan gangguan absorpsi makanan dan gagal tumbuh. Enteropati ini paling banyak disebabkan respon imun terhadap susu sapi dan kadang- kadang kedelai, biji-bijian (sereal), telur dan ikan laut. Pada pemeriksaan endoskopi dapat terlihat luka pada usus kecil, pemanjangan kripti, peningkatan limfosit intraepithelial dan eosinofil. ${ }^{13}$ Pada cow's milk protein sensitive enteropathy, diare kronik merupakan gejala yang mencolok. Hampir semua kasus mengalami gangguan pertumbuhan akibat gangguan absorpsi berbagai nutrien, kehilangan protein dan darah melalui saluran cerna, serta efek sistemik sebagai akibat interaksi antigen-antibodi. ${ }^{7}$

- Enterokolitis. Gejala enterokolitis ini hampir sama dengan sindrom enteropati, namun menunjukkan derajat yang lebih berat. Gejala pada bayi adalah muntah dan diare hebat sehingga dapat terjadi dehidrasi, letargi, asidosis dan methemoglobinemia. Gejala pada anak dapat terlihat seperti sepsis dengan jumlah leukosit polimorfonuklear darah perifer yang tinggi. ${ }^{8}$

Penyebab enterokolitis yang diinduksi protein ini sebagai akibat alergi terhadap protein susu sapi namun hampir setengahnya juga bereaksi terhadap kedelai. Beberapa jenis makanan tambahan yang dapat menimbulkan enterokolitis adalah beras, gandum dan biji-bijian (cereals). Diagnosis biasanya dapat ditegakkan tanpa melakukan biopsi. ${ }^{13}$

- Penyakit Celiac (Celiac disease). Penyakit celiac terjadi sebagai akibat respon imun terhadap protein makanan (gluten) sehingga dikelompokkan dalam

Tabel 1. Berbagai gangguan gastro intestinal dan proses yang mendasari ${ }^{8,13}$

\begin{tabular}{ll}
\hline \multicolumn{1}{c}{ Mekanisme } & \multicolumn{1}{c}{ Gangguan gastrointestinal } \\
\hline Diperantarai IgE & Oral allergy syndrome $(O A S)$, anafilaksis gastrointestinal \\
Tidak diperantarai IgE & Enterokolitis, proktokolitis, sindrom enteropati, penyakit celiac (celiac disease) \\
Gabungan diperantarai IgE dan non-IgE & Gastroenteropati eosinofilik \\
\hline
\end{tabular}


alergi makanan. Gejala yang timbul meliputi mual, muntah, diare, dan gagal tumbuh. Gejala awal bisa tampak pada tahun pertama kehidupan namun gambaran yang spesifik bermanifestasi setelah anak berumur satu tahun. Lebih dari 95\% anak memiliki antigen HLA DQ2. ${ }^{13}$

3. Alergi makanan yang merupakan kombinasi $\operatorname{IgE}$ mediated dan non IgE mediated

- Gastroenteropati eosinofilik. Pasien menunjukkan gejala mual setelah makan, disfagia, nyeri perut, muntah, diare, nyeri epigastrium yang hebat dan jika terjadi inflamasi yang luas dapat terjadi obstruksi. ${ }^{7}$ Penyakit ini ditandai dengan adanya riwayat di dalam keluarga dan eosinofil yang meningkat pada darah perifer hingga $60 \%$ dari total jumlah leukosit. ${ }^{7}$ Perlu adanya konfirmasi dengan pemeriksaan biopsi yaitu ditemukan adaanya infiltrasi eosinofil pada dinding saluran cerna. ${ }^{13}$

\section{Prognosis}

Umumnya alergi makanan akan menghilang dalam jangka waktu tertentu, kecuali alergi terhadap kacang tanah, nuts, ikan laut, dan kerang-kerangan. ${ }^{1}$ Sekitar $85 \%$ anak dapat mentolerir kembali makanan yang mengandung susu sapi, telur, kacang kedelai, dan gandum sebelum berumur 3-5 tahun. ${ }^{3}$ Keadaan ini disebabkan karena mukosa usus dan sistem imun yang makin matur, juga akibat menurunnya sensitivitas dari target organ. ${ }^{7}$ Uji provokasi perlu dilakukan terhadap makanan tersebut setelah eliminasi selama 4-6 bulan. ${ }^{10}$

\section{Kesimpulan}

Alergi makanan adalah bagian dari reaksi simpang makanan yang didasari proses imunologis. Gejala alergi makanan pada gastrointestinal sangat bervariasi dari perasaan nyeri, mual, muntah, diare, malabsorpsi hingga gangguan pertumbuhan. Umumnya alergi makanan akan menghilang pada umur 3-5 tahun kecuali alergi terhadap kacang tanah dan sejenisnya, ikan laut dan kerang-kerangan.

\section{Daftar Pustaka}

1. Zakiudin M. Alergi makanan pada anak. Disampaikan pada Pendidikan Kedokteran Berkelanjutan Ilmu Kesehatan Anak FKUI XLV, Jakarta, 18-19 Februari 2002.

2. Ariyanto H. Alergi makanan. Dalam: Arwin AP, Corry SM, penyunting. Buku ajar alergi imunologi anak. Jakarta: BP IDAI, 1996. h. 204-14.

3. Hoffman KM, Sampson HA. Evaluation and management of patient with adverse reactions. Dalam: Bierman CW, Pearlman DS, Shapiro GG, Busse WW, penyunting. Allergy, asthma, and immunology from infancy to adulthood. Edisi ke-3. Philadelphia: Saunders, 1996. h. 665-84.

4. Wegrzyn AN. Future approach to food allergy. Pediatrics 2003; 111:1672-80.

5. Zeiger RS. Food allergen avoidance in the prevention of food allergy in infants and children. Pediatrics 2003; 111:1662-71.

6. Sicherer SH. Food allergy. The Lancet 2002; 360:70110.

7. Soetjiningsih. Alergi dan intoleransi terhadap makanan serta manifestasinya di saluran pencernaan. Disampaikan pada Pertemuan Ilmiah Berkala Badan Koordinasi Gastroenterologi Anak Indonesia XI, Jakarta, 29 Juni-1 Juli, 1989.

8. Sampson HA. Update on food allergy. J Allergy Clin Immunol 2004; 113:805-19.

9. Breiteneder $\mathrm{H}$, radauer C. A classification of plant food allergens. J Allergy Clin Immunol 2003; 113:821-30.

10. Hendra Santoso. Masalah alergi makanan pada anak. Disampaikan pada Simposium Alergi Makanan, Denpasar, 7 Februari, 1989.

11. Per Brandtzaeg. Current understanding of gastrointestinal immunoregulation and its relation to food allergy. Ann NY Acad Sci 2002; 964:13-45.

12. Mayer L. Mucosal immunity. Pediatrics 2003; 111:1595600.

13. Sicherer SH. Clinical aspects of gastrointestinal food allergy in childhood. Pediatrics 2003; 111:1609-15. 